\title{
Correction to: Letter to the Editor: comment on 'Breast-conserving surgery with intraoperative radiotherapy in recurrent breast cancer: the patient's perspective' by Elfgen et al.
}

\author{
loanna Akrida ${ }^{1}$ (1) - Maria-loanna Argentou ${ }^{2}$
}

Published online: 8 September 2020

(c) The Japanese Breast Cancer Society 2020

\section{Correction to: Breast Cancer \\ https://doi.org/10.1007/s12282-020-01143-7}

In the original publication of the article, surnames and given names of the authors were interchanged. The correct names are given in this correction.

Publisher's Note Springer Nature remains neutral with regard to jurisdictional claims in published maps and institutional affiliations.

The original article can be found online at https://doi.org/10.1007/ s12282-020-01143-7.

Ioanna Akrida

joannakrida@yahoo.gr

1 Department of General Surgery, General University Hospital of Patras, Patras, Greece

2 Breast Unit, Department of General Surgery, General University Hospital of Patras, Patras, Greece 